\title{
The Impact of the Renegotiation of USCM on the Agricultural Exports of Sinaloa
}

\author{
Jose G. Vargas-Hernandez ${ }^{1 *}$, Icela Flores Osuna ${ }^{2}$, M. S. C. Omar Cristian Vargas Gonzalez ${ }^{3}$ \\ ${ }^{1}$ Research Professor, Department of Administration, University Center for Economic and Managerial \\ Sciences, University of Guadalajara, Periferico Norte 799 Edif. G207-7 Nucleo Universitario Los Belenes, \\ Zapopan Jalisco, Mexico \\ ${ }^{2}$ Facultad de Ciencias Sociales, Universidad Autonoma de Sinaloa, Av. Ejercito Mexicano Esq. Con \\ Universidad S/N, Av. de los Deportes, Telleria, Mazatlan, Sinaloa, 82017, Mexico \\ ${ }^{3}$ Master in Computer Systems, Instituto Tecnologico de Ciudad Guzman, Tecnologico Nacional de Mexico, \\ Av. Tecnologico 100, Ciudad Guzman, Jalisco, 49000, Mexico
}

\begin{abstract}
Mexico, like other countries, invested in measures to attract foreign direct investment to their territories. Therefore, the North America Free Trade Agreement (NAFTA) was signed in 1994 and NAFTA gave the status to Mexico as the largest direct exporter of the United States, a country that threatened to leave the treaty by renegotiating USMC. This research is carried out to determine the advantages and disadvantages of renegotiation based on Sinaloa's agricultural exports, with the question of whether it would negatively impact the USMC renegotiation of Sinaloa's agricultural exports, with the hypothesis that renegotiation of USMC has a negative effect on Sinaloa agricultural exports. This paper demonstrates that the results confirm the hypothesis employed.
\end{abstract}

Keywords: NAFTA, Renegotiation, Sinaloa Exports

\section{Introduction}

In Eduardo Galeano's book The Open Veins of Latin America, he stipulates the phrase: The people who buy, rule, the people who sell, served; trade must be balanced to ensure freedom; the people who want to die sell to only one people and the people who want to save sell to more than one (Galeano, 1970).

The regional agreement called the Mexico, North American Free Trade Agreements (NAFTA) signed between the governments of Mexico, Canada and the United States in 1992 that entered into force in 1994, created a free trade area at a reduced cost for the exchange of goods between the three countries. It has been recently renegotiated as United States, Mexico and Canada Treaty (USMC in English or TEMC in Spanish). President Donald Trump was in a renegotiation crisis due to the entry into power of the government of the United States, who proposed to rearrange the rules established in the treaty with faithful benefits in his favor and if not, announced the departure of the country from the agreement. This has already been finalized, but there is in Mexico a wave of uncertainty about what would happen to its exports, since it is the main supplier of raw materials and a variety of merchandise to the United States.

Therefore, it is of utmost importance to investigate and determine the impact of the renegotiation of the TEMC on Sinaloan agricultural exports, a state called "the granary of Mexico" for its wealth in agricultural crops and which has earned the first place of exploitation of these raw materials to be exported to the neighboring country, the United States.

That is why this research work is aimed at determining the advantages and disadvantages in production, trade 
and distribution network that will prevail after the renegotiation. Taking as indicators, the final trade arrangements between the United States, Mexico's exports and trade, the Gross Domestic Product (GDP), GDP per capita and transportation logistics for export shipments. Which concludes that the general hypothesis has a negative result.

\subsection{Background}

In 1994 the North American Free Trade Agreement (NAFTA, now TEMC) entered into force, an innovative treaty aimed at opening and expanding the North American market. Since then, the NAFTA has systematically removed most of the tariff and non-tariff barriers to trade and investment between Canada, the United States and Mexico, leading to the establishment of a stability and confidence framework for long-term investments. The TEMC was preceded by the CanadaUnited States Free Trade Agreement (EXPANSION, 2017, p. 34).

Currently, a series of changes have emerged in the decisions of the governments involved in the TEMC, mainly the United States. Therefore, it is of utmost importance to research a viable investigation about the impact of the renegotiation on Sinaloa exports, since the state Sinaloa has earned the nickname of being the breadbasket of Mexico for the large amount of raw materials that the state produces. It is the number one state in supplying its agricultural products to the neighboring country (United States). That is why the present project is delimited in a spatial way to firmly base ourselves on determining the advantages and disadvantages that by the renegotiation of the TEMC were implemented in agricultural exports Sinaloans.

- Analyze the renegotiation of the TEMC.

- Determine the advantages of Sinaloan exports.

- Determine the disadvantages of Sinaloan exports.

- Analyze the productions of agriculture in Sinaloa.

- Analyze Sinaloa's trade in relation to the USA.

\subsection{Research Questions}

General question

- Will the renegotiation of the TEMC negatively impact Sinaloa's agricultural exports?
- What would be the production in Sinaloa's agricultural exports based on the renegotiation of the TEMC?

- How would trade in agricultural exports in Sinaloa be based on the renegotiation advantages of the TEMC?

- What would the distribution network in Sinaloa's agricultural exports look like depending on the disadvantages of renegotiating the TEMC?

\subsection{Justification}

Mexico, like other countries, invested in measures to attract foreign direct investment to its territories. Consequently, in 1994 it signed the NAFTA (North American Free Trade Agreement), with the United States of America and Canada, a treaty that imposed Mexico as the largest direct exporter to the United States, a country that would possibly exit the treaty by renegotiating the TEMC. Therefore, it is important to carry out this research to determine the advantages and disadvantages that for the above mentioned were implemented in Sinaloenses agricultural exports, which is one of the main export productions and source of employment for many Sinaloenses, it is expected that, if the renegotiation was not feasible for our country Mexico, it would have to abandon the said treaty.

\subsection{Research Objectives}

Main objective: To determine the advantages and disadvantages of renegotiating the TEMC based on Sinaloa's agricultural exports. Specific objectives:

a. Determine production in Sinaloa's agricultural exports based on the renegotiation of the TEMC.

b. Determine trade in agricultural exports from Sinaloa based on the renegotiation advantages of the TEMC.

c. Determine the distribution network in Sinaloa's agricultural exports based on the disadvantages of renegotiation of the TEMC.

\section{Theoretical-empirical Review of the Literature}

According to the classic free trade theory developed by David Ricardo, all countries win when they participate 
in a free trade zone. Theoretically, the idea that each country should specialize according to its comparative advantages has some logic (Dillon, 1991). The TEMC drives economic growth and dynamic trade, stimulates investment and at the same time creates productive alliances, adapts to small and medium-sized companies in a framework of fairness and certainty. TEMC. partners promote environmental protection and offer greater job opportunities in North America. (Audley, Demetrios, Papademetriou, Polaski and Vaughan, 2003).

After the declarations of Wilbur Ross, Secretary of Commerce of the United States, on "a sensible negotiation" of the North American Free Trade Agreement, experts see measure in the position of that country. The Secretary of Commerce of the United States, Wilbur Ross, seems to have given the TEMC a breather, after having said in an interview with the NBC network that a "sensible" renegotiation of the treaty would strengthen the weight, experts agreed (El Financiero, 2017).

"(This statement) indicates that not only (Trump) is taking a negotiating stance, it indicates that this stance, this softness, reflects the broad consensus that exists in the US, at least among companies, that there are great benefits for both countries (with the TEMC)," said David Shirk of the University of San Diego. On this side of the border, the analysis is similar; For Jessica de Alba, a researcher at the Anahuac University, this first warning from Ross is positive. It is a positive and encouraging reaction in terms of investments and free trade in North America (El Financiero, 2017).

For Ernesto O'Farrill, president of Bursametrica, Ross's comments indicate that in the US they are willing to modernize the trade agreement and not abandon it. "The statements are far from the initial position that Mexico was going to bend in the TEMC negotiation, and threatened to leave unilaterally. The statements are showing that the TEMC is alive and can undergo a modernization process," he assured. The decision to strengthen the Mexican peso may have the objective of preventing Mexico from having an unfair advantage, in order to reduce its currency appreciation, which, in turn, means that the United States wants to continue trading with the country added O'Farril. He explained that the third line of actions focuses on discovering ways to raise wages and improve the living conditions of Mexican workers (El Financiero, 2017).

With this it is understood that it can be a measure to discourage migration to the northern country. For ranchers, the situation shows an opening gesture. "(Washington) has made it clear that they are aware today of negotiating the treaty and that this is convenient for us. In this situation that we have a sensible dialogue on foreign trade, we applaud and congratulate it because it is what our countries require", said Rogelio Perez, director of Mexican Beef, the exporting branch of the Mexican Association of Livestock Fattening (AMEG) (El Financiero, 2017).

However, Shrik warned that while it may be perceived that the balance is now tilting more on the side that the TEMC will be maintained, it should not be thought that what a cabinet member says is precisely the same as Trump thinks, because a constant in the little more than two years that Trump had been in office is the uncertainty in his relationship with Mexico. "We don't know who we're going to wake up with tomorrow," Shrik said, referring to Trump's fickleness. In contrast, Arturo Perez Behr, president of the National Association of Importers and Exporters of the Mexican Republic, expressed caution before Trump's comments (El Financiero, 2017).

"The fact that there is talk of renegotiation and no longer a cancellation of the TEMC, is a positive issue, the threat issues are decreasing, it is a good way, but that does not mean that we no longer have to be on the lookout for statements that President Donald Trump makes, hopefully that is already the speech of the government in general," he said. He explained that Asian countries such as China have taken advantage of what the TEMC establishes legally, so it cannot be considered as abuse. "We have to advocate for our country, whatever suits Mexicans," he added. (El Financiero, 2017).

\subsection{Agricultural Free Trade: Theory and Reality}

In a bilateral FTA it is not feasible to negotiate internal aid because it is impossible in practice to identify 
which products enter a country with aid and which do not. Therefore, domestic aid has not being negotiated in this treaty with the United States (Mypimes, 2017). Today there is a general consensus regarding the benefits of the economic integration of nations. Free trade is good because it allows access to a greater number of goods and at lower prices, which should increase social welfare. It allows access to cheaper inputs and capital goods, which should increase the competitiveness of the productive sectors that add value.

Free trade promotes the efficient allocation of resources because price signals are not distorted: When there is a shortage of a good, its price rises and producers receive the signal to increase supply (and consumers to reduce demand); when there is abundance of a good, its price falls and producers receive the signal to reduce supply (and consumers to increase demand) (Mypimes, 2017).

Finally, from a macroeconomic point of view, opening the current account of the economy is equivalent to opening the economy to the savings of the rest of the world. However, the reality of international trade, in the specific case of the agricultural sector, is far from that first best theoretician called free trade. Why? To resolve this question, it is necessary to understand that the agricultural sector is special and different from the other sectors of the economy and that the conservation of agricultural activities translates into a benefit for all of society. When a product is purchased from a peasant, not only the product itself is received, but also the lawful and peaceful occupation of the national rural territory (Mypimes, 2017).

In other words, in addition to a product, peace and tranquility is also received from the peasant in the countryside and, therefore, peace and tranquility in the cities. Of course, this positive externality for society would never be reflected in the free market price of agricultural products. But since societies value this positive externality, it then can be accepted distortions in the price of some products in the agricultural sector in order to make them economically viable and profitable for farmers (Mypimes, 2017).
In practice, international trade in the agricultural sector suffers from types of distortions or barriers.

- First, there are the tariff barriers. These include advalorem tariffs (percentage of the price of the good), specific tariffs (a certain value on the price of the good), quotas (import quotas).

- Second, there are the non-tariff barriers, whose restrictive effects on trade are in many cases greater than the tariff barriers. Among these types of distortions, the sanitary technical and phyto/zoo standards that are imposed for the importation of products stand out.

- Third, we have export subsidies. Given their fiscal capacity, developed countries prefer to protect the rural sector with domestic aid and export subsidies.

Developing countries have to resort to tariff barriers to protect our rural producers. It is very important to keep in mind that what is negotiated in an FTA is border support (tariffs). The reason is simple. In a bilateral FTA it is not feasible to negotiate internal aid because it is impossible in practice to identify which products enter a country with aid and which do not. Therefore, domestic aid has not been negotiated in this treaty with the United States (Mypimes, 2017).

- First, because, just as the United States cannot negotiate in this treaty the internal aid that its producers receive.

- Second, because as the Democratic Security policy progresses successfully and the defeat of the narco-terrorist threat becomes more evident, there will be considerable and increasing increases in employment and in national agricultural production.

- Third, because EU, it is the main commercial partner of Colombia. In effect, it receives $40 \%$ of our agricultural exports and our trade balance with said country has a surplus of 500 million dollars (approximately 1,100 million dollars of exports against 600 million dollars of imports).

- Fourth, because the United States is the richest market in the world. It is made up of 300 million consumers with an average annual income of $\$$ 30,000 per person. 
- Fifth, because the United States is a protected market and therefore a high-price market for many agricultural products.

- Sixth, because if the treaty was not negotiated and signed the FTA, Mexico will lose preferential access to the United States market at the hands of our competitors who have already signed an FTA with that country (Central America, Chile, Australia, etc.).

- Seventh, because the signing of the treaty is the way to perpetuate beyond 2006 the benefits and job creation attributable to the preferences that the United States grants us with the Atpdea.

- And eighth: because as security, technological development and advances in infrastructure (irrigation and roads) generate increases in the productivity of the agricultural sector, the profitability of agricultural activities will increase (Mypimes, 2017).

\subsection{Empirical Review of the Literature}

In 1994, the North American Free Trade Agreement (TEMC) entered into force, creating one of the largest free trade zones in the world and establishing the basis for strong economic growth and greater prosperity for Canada, the United States and Mexico. For 15 years, the TEMC has demonstrated how free trade contributes to increased wealth and competitiveness by providing true benefits to families, farmers, workers, manufacturers and consumers. (NAFTA de hoy, 2017).

The North American Free Trade Agreement (NAFTA) is a regional agreement between the Government of Canada, the Government of the United Mexican States and the Government of the United States of America to create a free trade zone (Secretariado del TLCAN, 2017). The North American Free Trade Agreement (NAFTA) or United States, Canada and Mexico Agreement (TEMC) is the set of rules that Mexico, the United States and Canada agree to sell and buy products and services (Castro, 2008).

Export is to send national or nationalized goods for use or consumption abroad (Minister of Foreign Affairs and Cooperation, 2017). Exports are sent abroad to obtain plant products through knowledge developed by man, destined to cultivate the land. Production sent abroad from the primary sector that uses cultivation as its main activity obtains raw materials.

\subsection{Contextual Framework of Exports in Sinaloa}

According to data from the SEDECO COFOCE information system, in Sinaloa at the end of 2015, the agro-food and agriculture sectors contributed $62 \%$ of total exports in the State. According to this source, the main exporting company in Sinaloa is Sukarne SA de CV Grupo VIZ, with a participation of almost $28 \%$ of total exports. Followed by the auto parts company located in the city of Los Mochis, Deplhi de Mexico SA de CV and Envases Universales de Mexico which is in Mazatlan and the agro-industrial sector Citrofrut and Conservas La Costena, with operations in Rosario and Guasave. The existing companies at the end of 2015 registered in this system were 607 exporting companies (CODESIN, 2017). See table 1 below.

\subsubsection{Countries opened their market to Mexican products in 2016}

In 2016, 14 countries opened their markets to receive, some for the first time, others after certain limitations, animal products from Mexico. As a result of the negotiations of sanitary protocols carried out by SAGARPA with the authorities of 14 countries and the European Union, the opening of markets was achieved in 2016 for 18 Mexican products, nine of animal origin and nine vegetables, explained the federal agency. Due to the negotiations that were carried out through the National Service of Health, Safety and Agro-Food Quality (Senasica) with various nationals, the prohibition to export pathogen-free eggs and egg products to the European Union was lifted and the market for Mexican honey reopened in Saudi Arabia (Torres, 2017).

Agro will have a privileged place in any negotiation: SAGARPA regarding products of plant origin, since last year, Mexico has exported blueberry to China; table grape from Sonora to Australia; tomato seedlings to the United States and sugar cane (in vitro or hardened) to Peru. In addition to sorghum brushes to Chile; stevia plants to Guatemala; corn seed to Ecuador; Chili seed to Portugal and amaranth grain for consumption in the 
neighboring northern country, Turkey and the European Union (Torres, 2017).

According to information from SAGARPA, the following years, it is expected to expand the offer of Mexican products abroad, for which talks have already started with health services from more than 15 nations. About 13 Mexican products of Mexican origin are expected to "step on" the land of countries such as Russia, China, Indonesia, Iran, Singapore, Vietnam, Taiwan and Japan for the first time (Torres, 2017).

\section{Materials and Methods}

\subsection{Type of Research}

It is an exploratory investigation. It has the primary objective to facilitate a greater penetration and understanding of the problem that is faced. It is analytical because it is descriptive and is more linked to statistical and control data, in order to generate a hypothesis about what happened, or to occur, predict failures or events. The research is also of an empirical type since it is based on experimentation or observation (evidence).

\subsection{Research Design}

Table 1. Research design

\begin{tabular}{|c|c|c|c|c|c|c|}
\hline Variable & Description & Dimensions & Indicators & $\begin{array}{l}\text { Research } \\
\text { instruments }\end{array}$ & $\begin{array}{l}\text { Operacionalization of } \\
\text { variables }\end{array}$ & Statistical analysis \\
\hline XO USMC-TEMEC & $\begin{array}{l}\text { "The North American Free } \\
\text { Trade Agreement or NAFTA } \\
\text { is a trade agreement } \\
\text { between the three } \\
\text { countries in North America: } \\
\text { Canada, the United States } \\
\text { of America and Mexico." } \\
\text { (USMC-TEMEC, 2016: } \\
\text { s.p.). } \\
\text { (NAFTA, 2016: s.p.). }\end{array}$ & $\begin{array}{l}\text { Renegotiation } \\
\text { Advantage } \\
\text { Disadvantages }\end{array}$ & $\begin{array}{l}\text { US exit from the } \\
\text { treaty. } \\
\text { Exports } \\
\text { Commerce }\end{array}$ & $\begin{array}{l}\text { Bibliographic } \\
\text { analysis } \\
\text { Hemerographic } \\
\text { Analysis }\end{array}$ & $\begin{array}{l}\text { Review of practical case } \\
\text { Bibliographic analysis }\end{array}$ & $\begin{array}{l}\text { Analytical Study } \\
\text { Exploratory study } \\
\text { Empirical study }\end{array}$ \\
\hline $\begin{array}{l}\text { Y0 } \\
\text { Agricultural Exports }\end{array}$ & $\begin{array}{l}\text { Product of the primary } \\
\text { sector that you dare } \\
\text { from cultivation as } \\
\text { a production activity } \\
\text { obtains raw materials }\end{array}$ & $\begin{array}{l}\text { Production } \\
\text { Commerce } \\
\text { Red de distribution }\end{array}$ & $\begin{array}{l}\text { GDP distribution } \\
\text { network } \\
\text { GDP per capita } \\
\text { in Sinaloa } \\
\text { Opening to new } \\
\text { markets } \\
\text { Logistics }\end{array}$ & $\begin{array}{l}\text { Bibliographic } \\
\text { analysis } \\
\text { Hemerographic } \\
\text { analysis }\end{array}$ & $\begin{array}{l}\text { Review of practical case } \\
\text { Hemerographic Analysis }\end{array}$ & $\begin{array}{l}\text { Analytical Study } \\
\text { Exploratory study } \\
\text { Empirical study }\end{array}$ \\
\hline
\end{tabular}

Source: self-made

\subsection{Research Construct}

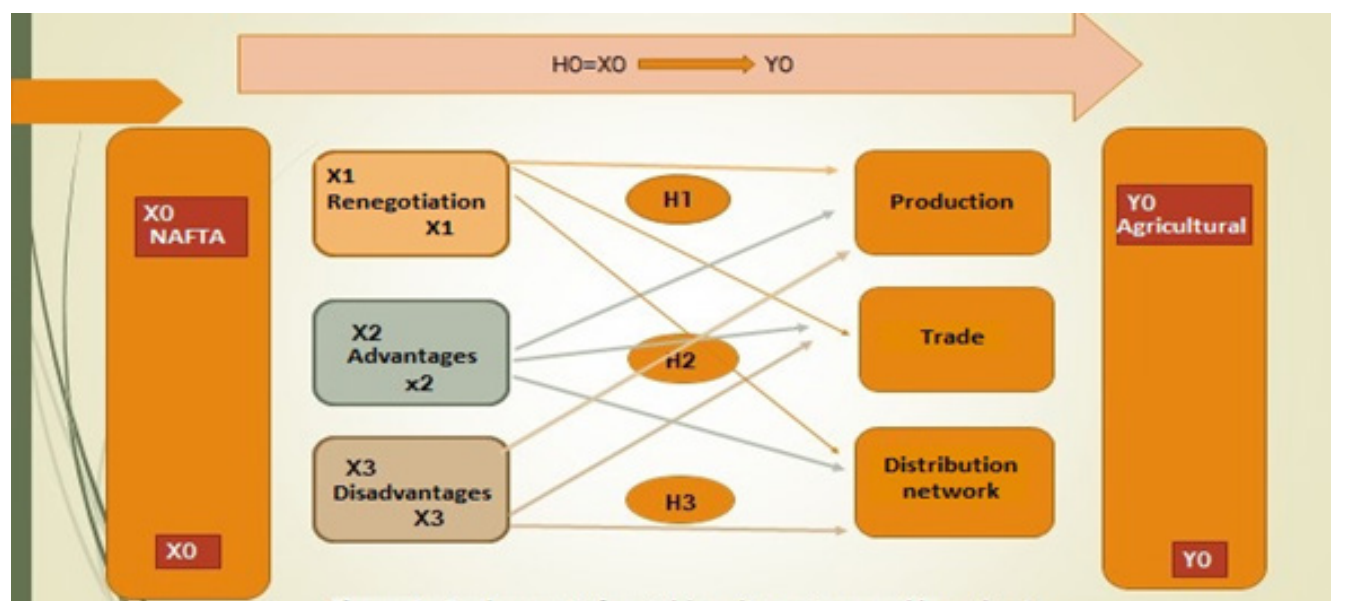

Figure 1. Research construct.

Source: Self-made. 


\subsection{Research Instrument}

The instrument used in this research project is bibliographic analysis and hemerographic analysis because it focuses on the renegotiation of the NAFTA (North American Free Trade Agreement) for which this research is based mainly on agricultural exports of the state of Sinaloa was proposed with indicators such as the US exit from the TEMC, Exports-Trade, GDP and GDP Per capita of Mexico, opening to new markets, logistics. Materials and methods should be described in sufficient detail to allow others to replicate and build on published results.

\subsection{Data Analysis}

\subsubsection{Quarterly GDP Growth Annual Rate}

The Mexican economy grew $2.9 \%$ at an annual rate in the first quarter of 2016, according to preliminary figures from the National Institute of Statistics and Geography (INEGI). This advance represents the best first quarter for Mexico since 2013 and the highest quarterly growth since the second quarter of 2014.

\subsubsection{Growth of the Primary Sector}

While the primary activities, that is, those related to agriculture, advanced $3 \%$ at the annual rate, surpassing the $2.9 \%$ advance that occurred last year.

\subsubsection{Depreciation impact on Wealth of Mexicans}

GDP per inhabitant represents the economic value of the goods and services generated by a nation that would correspond to each inhabitant if wealth were distributed equitably (BANXICO, 2017) (CONAPO, 2017). The Gross Domestic Product (GDP) is the value of the final goods and services produced by a country during an established period. GDP per capita or per capita is this same measure, but divided by the population of a country. In 2014, the GDP per capita for Mexico reached its highest level in history, but only two years later, this measure registered a drop of more than $20 \%$.

The GDP per capita represents the economic value of the goods and services generated by a nation that would correspond to each inhabitant if wealth were distributed equitably. This implies that, if a country's Gross Domestic Product increases while its population remains stable, then the GDP per capita increases; but if the population increases while the GDP remains constant or decreases, then the GDP per capita will also decrease.

\subsubsection{Export Logistics}

The success of international trade in any country or region is essential without an access door that allows the proper transit of goods and services. In Mexico, the port of Veracruz is an example of the country's commercial and industrial development since the $16^{\text {th }}$ century. Today, its importance is indisputable and its challenges are increasingly complex, as the evolution of industrial processes and the type of goods test any logistics system. The logistics chain begins with the production of the raw material and ends at consumption centers. In this sense, seaports are nodes in the physical network of maritime transport; and their competitiveness depends on the fact that those they offer are fast, flexible and safe for international trade and shipping lines.

According to a study by the Inter-American Development Bank (IDB, 2017) (IDB) on cargo logistics in Latin America and the Caribbean, there are at least three perspectives to consider understanding the importance of the logistics process in an economy: the generator cargo (industry), cargo operator (services) and the public policy environment. It is the orderly interaction of these three elements that allows logistics operation costs to be consistently reduced over time.

In the first stage of the expansion, 16,000 million pesos will be invested by the Federal Government and by the end of the project in 2030, they will have invested 70,000 million pesos, of which 42,000 would be private and 28,000 publics. The World Bank (Banco Mundial, 2010) (WB) ranked Mexico, in 2010, in $50^{\text {th }}$ place out of 155 countries with a performance of 3,051. Some consultancies have estimated that logistics costs in Mexico represent $15.3 \%$ of the Gross Domestic Product (GDP). The logistics costs of Mexican companies are $10.3 \%$ of sales, of which $40 \%$ correspond to transportation costs and $60 \%$ to 
inventories; order processing, storage and planning of transportation operations management (Market, Real Estate, 2017).

Recently, the federal government and the IDB carried out a study on the National System of Logistics Platforms (SNPL) (National System of Logistics Platforms, 2017), which defined that the system would be made up of 85 logistics platforms, highlighting the investment of infrastructure and services, to increase the efficiency of supply chains. In this context, it can be observed the performance of Mexican ports in recent years. For example, in 2010, commercial imports by sea were 75.2 million tons and 122.2 million tons were exported to all regions of the world. In 2013, 81.1 million tons were imported and 129.1 million were exported (Market, Real Estate, 2017). This increase was possible because Mexico traded this way, both on the Gulf and Caribbean coast (15 ports) and in the Pacific Ocean (20 ports), the port of Veracruz being the most representative for the manufacturing industry.

According to the Economic Commission for Latin America and the Caribbean (ECLAC, 20) (CEPAL, 2014), in the ranking of containerized port movements in the 2010 region, the port of Veracruz ranked $18^{\text {th }}$; and for the first semester of 2013 it was ranked 16. On the other hand, in 2014, according to the study of port technical efficiency, prepared by the IDB, the port of Veracruz occupies the $22^{\text {nd }}$ efficiency site of a total of 63 ports in Latin America and the Caribbean (Market, Real Estate, 2017). The port of Veracruz is the most important commercial port in the country. Through it, $100 \%$ of purely commercial cargo transits and the only one that significantly operates the six most important cargo segments nationwide:

Exports registered a decrease of $10.7 \%$ when moving 4,730, 856 tons (SICE 2 de 07 de 2017). Trade has as a priority to carry out the expansion of the port because this will promote employment and will boost the economy of the region and the state. The entities where most of these vehicles come from are: Puebla, Estado de México, Aguascalientes, Coahuila, Tamaulipas, Nuevo León and Veracruz. This port is the most representative for the export and import of motor vehicles. According to the following data, the port of Veracruz moves $66 \%$ of total vehicle exports by sea (Market, Real Estate, 2017).

In addition, the port of Veracruz, with respect to the movement of vehicles in roll on/roll-off, has a performance of 128.8 UHBO (unit of hour ship in operation). Currently, the port of Veracruz has 48 companies that offer related services in terms of: For the Mexican State, the development of the maritime-port subsector is key to the economic growth of the country; therefore, the interaction of the private sector and the government is important, and the latter has the task of carrying out public policies in order to strengthen and make it more efficient as well as modernizing it.

In the coming decades, the port of Veracruz will be one of the most important logistical-maritime enclaves in the country and on the Atlantic coast to communicate the central region of Mexico with the markets of the United States and Europe. Likewise, it will connect the national industry with global supply chains, which will allow it to be more competitive and face the challenges of global trade and manufacturing (Market, Real Estate, 2017).

\subsection{Export Movements by System, Mexico 2013}

In this pie chart it is made clear that the most used transportation in Mexico for 2013 is by land, followed by sea.

The three products with the highest export of Sinaloa are Tomato, Corn and wheat. Sinaloan Exports Of the total Sinaloan exports to other countries, $82.5 \%$ corresponds to sales to the United States market. In income, this represents $8.9 \%$ of the State Gross Domestic Product. During 2014, Sinaloa exported products for about 770 million dollars, which represented $0.2 \%$ nationally. The main shipments were tomato, chickpea, beef, fish oil and flour, shrimp, squid and tuna. The North American Free Trade Agreement (TEMC), which the United States intends to renegotiate, has represented a $339 \%$ growth in the value of Mexican exports to the United States since its implementation.

Nationally, more than $80 \%$ of exports go to the United States. This represents a high dependency of the 
country's productive sectors with the neighbor to the north. And the larger a states trade with the United States, the greater its vulnerability. Vegetables were the main product in the period from January to June 2010. In the same period, the 10 main imports from the North American market to our country were corn, soy, soy residues, wheat, pork ham, other foods, boneless meat, powdered milk and cream, fructose and starch waste.

Twenty-two states in Mexico export vegetables to the United States. These exports represented about 583 thousand 795 million dollars, Guanajuato being the leading state. 21 other states imported vegetables from the United States for 23 million 139 thousand dollars. That 2014, Sinaloa exported vegetables to the northern neighbor for a value of 12 million 139 thousand 433 dollars. In turn, it imported American vegetables for $\$ 84,628$. Thus, the value of the exports of vegetables from 22 states to the United States exceeds their imports.

The bilateral relationship is key. If the United States market is important to Mexico, the same thing happens in reverse. According to the United States Department of Commerce, Mexico is the second destination for exports from that country with $15.7 \%$ of the total, preceded by Canada with $18.6 \%$ and is the third largest provider, with $13.1 \%$ of imports, after China, which accounts for $21.5 \%$ and Canada, which accounts for $13.2 \%$. For example, Mexico is the second commercial partner of the state of Michigan (our country receives $31.03 \%$ of the total exports of that North American entity). In the case of California, the Mexican market imports 12.53 of the products that that entity sends abroad. For Nebraska this is $14.53 \%$.

\subsection{Vegetable Exports and Imports, Mexico-EU}

It is noteworthy that the US content of Mexican exports to the American market is almost $40 \%$ of the components of these products, according to the National Bureau of Economic Research. Renegotiation, under the magnifying glass announced revision of the Free Trade Agreement draws the attention of the economic sectors of our country. Achieving maintenance and expansion of the agreements is an urgent need for many states highly dependent on the United States market for their exports.

In the case of Sinaloa, this commercial relationship represents $8.9 \%$ of the state GDP and this is mainly for food. There are other more vulnerable entities. Examples of this are Chihuahua, Baja California, Coahuila and Tamaulipas. For all these states, exports to the United States represent more than $50 \%$ of its Gross Domestic Product and for the most part, are from the manufacturing sector (El debate, 2017).

\subsection{Research Limitations}

During the preparation of this research, there were time limitations since it was carried out during a seven-week stay and the research period could not be exceeded. The money limitation was found since the necessary financial resources were not available to carry out a field research, data collection since the variable "Y" which is agricultural exports made it difficult to extract information, and reliability due to the information collected.

\section{Results}

As an analysis of the results of this research, Mexico has quarterly GDP growth at an annual rate in the last three years with a constant $2 \%$, GDP per capita has been increasing until 2014, where from that year it has been decreasing, it has a behavior of the primary sector that has been in constant change for 2015, down to minus 1 but for 2016 it has increased up to $6 \%$ according to the financier, Mexico's exports to the US have grown by $339 \%$ in terms real since the implementation of the NAFTA with less quantity are imports by Mexico from the US with $151 \%$.

Mexico-US trade has been in constant change, it is currently at $81 \%$, in 2014 the Mexican states exported to the United States for a total value of 583 million 794 thousand 468 dollars, Sinaloa with the amount of 12,139, 4443 dollars of which the three exported vegetables are tomato, corn and wheat, Mexico imported a smaller quantity of US vegetables for a total value of 23 million 139 thousand 098 dollars, Sinaloa 
exports to the US $82.5 \%$. Of the Sinaloan exporting companies in first place is Graneros United with 34, $893,112.75$ (USD) with participation of 1.35 and in the general ranking of exporting companies is in $12^{\text {th }}$ place. In second place, Agroindustrias de Andar de Delicias SA de CV with $28,883,344.53$ with participation of 1.13 in the general position 14 and in third place Agroexportadora del Noroeste SA de CV with 24, 127, 318.57 participation 0.94 according to CODESIN.

In 2010, the World Bank places Mexico in $55^{\text {th }}$ place out of 155 countries with transportation performance $15^{\text {th }}$ in port technical efficiency according to the economic commission for Latin America. According to Yuridia Torres, the financier Mexico can expand and open its market to new countries such as China, Australia, Peru, Chile, Guatemala, Portugal, Turkey, Russia, Indonesia, Iran, Singapore, Vietnam, Taiwan, Japan, and the European Union. It would be a greater advantage if the renegotiation of the TEMC were not to be satisfactory for Mexico.

\subsection{Hypothesis Testing}

The general hypothesis stipulates that the renegotiation of the TEMC has a negative effect on Sinaloan agricultural exports, with the in-depth investigation that was carried out, it is concluded that possibly if the United States decides to exit the treaty, it would greatly affect Sinaloa. As the main export destination to that country with $82.5 \%$ sales to its market, but this is no longer a fact with greater probability since President Donald Trump is considering renegotiation after the new elections in Mexico in 2018 to further facilitate the procedures that they are necessary and not the final solution, which leads us to conclude that the hypothesis is negative.

- Renegotiation together with the advantages and disadvantages has a direct relationship with agricultural production in Sinaloa, with a serious negative effect, since overproduction would be created if the new destination for exporting from Sinaloa was not quickly available.

- Renegotiating together with the advantages and disadvantages has a direct relationship with agricultural trade in Sinaloa, it would negatively affect since Sinaloa would be left without its main export destination, but it would have the alternative of opening up to send its products to new countries like China, Peru, Chile, Guatemala, Portugal, Turkey, Russia, Indonesia, Iran, Singapore, Vietnam, Taiwan, Japan and the European Union, which are countries that in 2016 opened their market to Mexico.

- The renegotiation together with the advantages and disadvantages has a direct relationship with the agricultural distribution network in Sinaloa, it would greatly affect the sea and land ports since they are the most popular transportation routes in Mexico, being used more frequently auto transport and later the seaports, the most used being the one in Veracruz.

\subsection{Contributions}

Mexico is a very capable country, with sufficient resources to stand out before other countries in Latin America and the world, it is only a matter of having an efficient president who knows how to take advantage of and exploit the riches of this country, who focuses on being persevering and growing every day more to become a developed country, increasing the quality of life of its inhabitants. Mexico should not be so dependent on the United States since it can maintain its economy even without its support. It must eliminate prejudices and uncertainties and export its productions to new markets, risking out of their comfort zone to obtain even more favorable results for the Mexican economy.

\subsection{Implications}

This research can be of great help to the main agricultural exporting companies in Sinaloa, to different secretaries such as, Secretary of Economy, SAGARPA, SEDECO, SENASICA, PROMEXICO, Chambers of Commerce, students of the Autonomous University of Sinaloa (UAS) to the degrees of Economy and International Commerce.

\subsection{Possible Line of Investigation}

In this context, the expansion of the Veracruz port complex, which is expected to be completed in 2025, is an indicator of public policy aimed at strengthening the port network. With a total investment of 60,000 million pesos and 23,933 million pesos between 2013 
and 2018, the port will achieve the highest number of maritime entries and freight mobility in accordance with the National Infrastructure Program 2014-2018. With this, an expansion of the port in the north is expected in: breakwater, navigation channel, piers and specialized terminals, specialized equipment, new yards and storage area.

\subsection{Research Limitations}

In this research, there were different limitations due to the difficulty of obtaining specific information when compiling the concepts that defined the variable "Y", which is called agricultural exports and the reduced amount of time that it had to carry out the research project.

\section{Conclusions}

As a general conclusion of this research project, it is obtained that the renegotiation of the TEMC does not have to put Mexico in a wave of uncertainty regarding its exports since, if President Donald Trump accepted the renegotiation and not the immediate departure from his country of treaty indicates that a fair agreement was reached for the three countries included in this, which have different clauses that protect them from any unfair act that is intended to be done, this made us investigate new possibilities for export growth for Mexico since Countries like Chin, Australia, Singapore have opened their markets for Mexico to export to them, we obtained very satisfactory results since we found that it is one of the countries with the best logistics since it is in place 50 out of 155 countries.

\section{References}

Audley, J. J., Demetrios, G, Papademetriou, Polaski S. y Vaughan S. (2003). La promesa y la realidad del USMCTEMEC, lecciones de Mexico para el hemisferio, Mexico, Recuperado el (23 de 07 de 2017). http://carnegieendowment.org/pdf/files/NAFTA_Spanish_fulltext.pdf.

Banco, Mundial. (2010). PIB y PIB per capita de Mexico, Banco Mundial, Mexico, consultado el 05/07/20177en. https://datos.bancomundial.org/indicador/NY.GDP. PCAP.CD.
Banxico. (2017). Desarrollo economico mexicano, Banco de Mexico, Mexico, Recuperado el 23 de 07 de 2017, de http:// www.banxico.org.mx/politica-monetaria-e-inflacion/ estadisticas/graficas-de-coyuntura/produccion-ventas-yprecios/producto-interno-bruto--varia.html.

Castro, A. (31 de 01 de 2008). Que es el tratado de libre comercio. El Universal, Recuperado el 15 de 06 de 2017. de http://archivo.eluniversal.com.mx/notas/478522.html.

CODESIN. (2017). Las exportaciones en Sinaloa, Consejo para el Desarrollo Economico de Sinaloa, Mexico. Recuperado el 21 de 07 de 2017. de http://codesin.mx/ news/las-exportaciones-en-sinaloa/: codesin.mx.

CEPAL. (2014). Tratados de libre comercio, América latina y el caribe, Comisión Económica para América Latina y el Caribe, consultado el 15/06/2017 de http://www.cepal. org/es/eventos/consulta-regional-america-latina-caribelac-politicas-publicas-la-implementacion-principios.

CONAPO. (2017). Estadísticas de exportación, México, Consejo Nacional de población, (G. D. Mexicana, Editor) Recuperado el 23 de 07 de 2017, de http://www.conapo. gob.mx/en/CONAPO/Mexico_en_cifras.

Dillon, J. (01 de 01 de 1991). Bases teoricas y prácticas de los tratados de libre comercio alc/USMC-TEMEC/gatt/ omc, Economista da Institution Ecumencial Coalition for Economic Toronto, Canadá, (E. D. Castro, Ed.) Recuperadoel20de06de2017,defile://C:/Users/Usuario/ Downloads/963-4082-1-PB.pdf: www.Users/Usuario/ Downloads.

El Debate. (05 de 03 de 2017). Exportaciones de Sinaloa. Mazatlan, Sinaloa, El debate, Recuperado el 15/07/2017 de. https://www.debate.com.mx/.

El Financiero. (21 de Julio de 2017). Economista, el financiero, Cd, Mexico, Recuperado el 23 de 07 de 2017 en: http://www.elfinanciero.com.mx/economia/el-pib-demexico-en-cinco-graficas.html.

EXPANSION. (23 de mayo de 2017). Economia internacional, Expansion, Mexico, Recuperado el 20 de 06 de 2017, en http://expansion.mx/economia/2017/05/23/ mexico-no-descarta-revision-de-reglas-de-origen-enrenegociacion-del-USMC-TEMEC.

Galeano, E. (1970). Las venas abiertas de América latina (la cueva ed., Vol. II). (R. Villagra, Ed.) Montevideo, Uruguay: siglo XXI editores. Recuperado el 20 de 07 de 2017.

Market, Real Estate. (2017). Artículos, Infraestructura y construcción, puerta para la industria-mexicana. Market, Real estate, México, Recuperado el 21 de 07 de 2017, de http:// www.realestatemarket.com.mx/articulos/infraestructuray construcción/15387-puerta-para-la-industria-mexicana: www.realestatemarket.com.mx. 
Ministro de Asuntos Exteriores y de Cooperacion. (junio de 2017). Exteriores de gobierno, Mexico, Ministro de asuntos exteriores y de cooperación., Mexico, recuperado 20/07/2017 en. http:/www.exteriores.gob.es/ representacionespermanentes/espanaue/es/quees2/ Paginas/El-Derecho-comunitario.aspx.

Mypimes (Ed.). (2017). Libre comercio agrícola, teoría y realidad, Mypimes Mexico, Recuperado el 25 de 07 de 2017, de http://www.tlc.gov.co/publicaciones/12942/libre_comercio_agricola_teoria_y_realidad: www.tlc.gov.com.

NAFTA de hoy. (01 de 01 de 2017). Tratado de libre comercio de america del norte, USMC-TEMEC de hoy, Mexico Recuperado el 19 de 07 de 2017, de https://www. sec-USMC-TEMEC-mex.org/Inicio/Bienvenida: www. sec-USMC-TEMEC-mex.org/.
Secretariado del TLCAN. (22 de 07 de 2017). NAFTA, Secretariado del USMC-TEMEC, USA, recuperado el 14/06/2017. de Https://www.nafta-sec-alena.org/Inicio/ Introducci $\% \mathrm{C} 3 \% \mathrm{~b} 3 \mathrm{n}$.

SICE. (2 de 07 de 2017). Comercio internacional, Mexico, Sistema de informacion sobre comercio exterior (O. D. Americanos, Editor) Recuperado el 02 de 07 de 2017. de http://www.sice.oas.org/Trade/nafta_s/Indice1.asp: sice. oas.org.

Torres, Y. (20 de 02 de 2017). 14-paises-abrieron-sumercado-a-productos-mexicanos-en-2016. México, El financiero, Recuperado el 19 de 07 de 2017. de http:// www.elfinanciero.com.mx/economia/14-paises-abrieron-su-mercado-a-productos-mexicanos-en-2016.html: www.elfinanciero.com.mx. 